\title{
High-risk Human Papillomavirus Testing for Triage of Women with Previous Cytological Abnormalities from the Vale do Ribeira Region
}

\section{Teste de papilomavírus humano para triagem de mulheres com alterações em citologia anterior provenientes da região do Vale do Ribeira}

\author{
Sandra Lorente ${ }^{10}$ Natália Coelho Couto de Azevedo Fernandes ${ }^{1}{ }^{(1)}$ Daniela Etlinger-Colonelli ${ }^{10}$ \\ Rodrigo Albergaria Réssio ${ }^{10}$ Sonia Maria Pereira de Oliveira ${ }^{10}$ Regina Maria Catarino ${ }^{10}$ \\ ${ }^{1}$ Department of Pathological Anatomy, Instituto Adolfo Lutz, São \\ Paulo, SP, Brazil \\ Rev Bras Ginecol Obstet 2020;42(6):340-348. \\ Address for correspondence Sandra Lorente, MSc, Instituto Adolfo \\ Lutz, Av. Dr. Arnaldo, 355-Cerqueira César $-7^{\circ}$ andar - Centro de \\ Patologia, São Paulo, SP 01246-000, Brasil \\ (e-mail: sandra_lorente@yahoo.com.br).
}

\begin{abstract}
Objective To evaluate the performance of the hybrid capture 2 ( $\mathrm{HC2}$ ) high-risk papillomavirus (hrHPV) assay and cytological test in women with previous abnormalities, to detect cervical intraepithelial neoplasia grade 2 or worse ( $\geq$ CIN 2).

Methods A cytological test and HC2 (Qiagen, Gaithersburg, Maryland, EUA) for hrHPV were conducted in 359 liquid-based (Sure Path, Becton Dickinson, TriPath Imaging, Burlington, NC, USA) samples collected from women from the Vale do Ribeira Region, during July 2013 and September 2015 with previous cytology classified as atypical squamous cells of undetermined significance (ASC-US), low-grade squamous intraepithelial lesion (LSIL), atypical squamous cells, cannot exclude high-grade squamous intraepithelial lesions (ASC-H), and atypical glandular cells (AGC). The histopathological examination was conducted in 179 women. The performance evaluations were calculated using the "exact" Clopper-Pearson 95\% confidence interval (Cl) test by MEDCALC (Medcalc Software Ltd, Ostend, Belgium).

Results The $\geq$ CIN 2 frequency was 11.7\% (21/179). The HC2 for hrHPV and repeat cytology to detect $\geq$ CIN 2 obtained, respectively, a sensitivity of $90.5 \%$ (95\% $\mathrm{Cl}=69.6-98.8)$ and $90.5 \%, \quad(95 \% \mathrm{Cl}=69.6-98.8)$, a specificity of $65.8 \%(95 \%$ $\mathrm{Cl}=57.9-73.2)$ and $43.7 \%(95 \% \mathrm{Cl}=35.8-51.8)$, a positive predictive value of $26.0 \%$

Keywords

- human papillomavirus

- screening

- cervical cancer

- papanicolaou test $(95 \% \mathrm{Cl}=21.4-31.3)$ and $17.6 \%,(95 \% \mathrm{Cl}=14.9-20.6)$, and a negative predictive value of $98.1 \%(95 \% \mathrm{Cl}=93.3-99.5)$ and $97.2 \%(95 \% \mathrm{Cl}=90.1-99.2)$.

Conclusion Hybrid capture 2 for hrHPV improves the performance of the detection of $\geq \mathrm{CIN} 2$, without compromising sensitivity, and provides a greater safety margin to return to the triennial screening of women undergoing follow-up due to previous abnormalities, without underlying $\geq$ CIN 2 .
\end{abstract}

received

September 19, 2018 accepted April 23, 2020
DOI https://doi.org/ 10.1055/s-0040-1712992. ISSN $0100-7203$.
Copyright $\odot 2020$ by Thieme Revinter

Publicações Ltda, Rio de Janeiro, Brazil
License terms

(c) (1) 


\section{Resumo}

\section{Palavras-chave \\ - papilomavírus humano \\ - rastreamento \\ - câncer do colo do útero \\ - papanicolaou}

Objetivo Avaliar o desempenho da captura híbrida $2(\mathrm{CH} 2)$ para papilomavírus humano de alto risco (HPVar) e repetição do exame citopatológico em mulheres com anormalidades em citologia anterior, para detectar neoplasia intraepitelial cervical grau 2 ou pior ( $\geq$ NIC 2).

Métodos Foi realizado exame citopatológico e $\mathrm{CH} 2$ para HPVar (Qiagen, Gaithersburg, Maryland, EUA) em 359 amostras em meio líquido (Sure Path, Becton Dickinson, TriPath Imaging, Burlington, NC, USA) coletadas de mulheres da região do Vale do Ribeira, durante julho de 2013 e setembro de 2015 com citologia anterior classificada como células escamosas atípicas de significado indeterminado (ASC-US), lesão intraepitelial de baixo grau (LSIL), células escamosas atípicas, não podendo excluir lesão de alto grau (ASC-H) e células glandulares atípicas (AGC). O exame histopatológico foi realizado em 179 mulheres. As avaliações de desempenho foram calculadas usando o teste de intervalo de confiança (IC) "exato" de Clopper-Pearson de $95 \%$ pelo software MEDCALC (Medcalc Software Ltd, Ostend, Bélgica).

Resultados A frequência de $\geq$ NIC 2 foi 11,7\% (21/179). A CH2 para o HPVar e a citologia de repetição para a detecção $\geq$ NIC 2 obteve, respectivamente, sensibilidade de $90.5 \%$ (IC $95 \%=69,6-98,8$ ) e $90,5 \%$ (IC $95 \%=69,6-98,8$ ), especificidade de $65,8 \%$ (IC $95 \%=57,9-73,2)$ e $43,7 \%$, (IC $95 \%=35,8-51,8)$, valor preditivo positivo de $26,0 \%$ (IC 95\%=21,4-31,3) e 17,6\%, (IC95\%=14,9-20,6), e valor preditivo negativo de $98,1 \%$ (IC 95\%=93,3-99,5) e $97,2 \%$, (IC 95\%=90,1-99,2).

Conclusão No geral, a $\mathrm{CH} 2$ para HPVar aprimora o desempenho para detecção de $\geq$ NIC 2, sem comprometer a sensibilidade e proporciona maior margem de segurança do retorno ao rastreio trienal de mulheres com anormalidades citológicas prévias, sem $\geq$ NIC 2 subjacente.

\section{Introduction}

Cervical cancer is the third most frequent neoplasia in the Brazilian female population, with an estimated incidence of 16,370 cases for $2018 .^{1}$ The persistent infection of the genital tract with high-risk human papillomavirus (hrHPV) types is one of the main causes for the occurrence of this disease, which has resulted in the development of tests for HPV nucleic acid detection. ${ }^{2,3}$ Most industrialized countries have introduced hrHPV assays; however, this methodology is not available to the women assisted by the Brazilian Unified Health System (SUS, in the Portuguese acronym), which recommend Papanicolaou (Pap) test to detect cervical cancer precursors, and the follow-up management of the women varies according to age and the type of lesion. ${ }^{4,5}$

Women with atypical squamous cells of undetermined significance (ASC-US) and low-grade squamous intraepithelial lesion (LSIL) must repeat the test after 6 months to 3 years, depending on the age, and they are referred to colposcopy in case of persistent cytological abnormalities. ${ }^{5}$ However, repeat cytology in these cases may increase the anxiety of the women and delay detection of more severe lesions masked by low-grade phenotype due to its low representativeness. ${ }^{6}$ Cytologies classified as atypical squamous cells cannot exclude high-grade squamous intraepithelial lesion (ASC-H), high-grade squamous intraepithelial lesion (HSIL) and atypical glandular cells (AGC), which, in Brazil, are referred to immediate colposcopy. ${ }^{5}$ Indeed, there is a consensus that all women with HSIL require colposcopy assessment; however, there are still divergences regarding the management of women with ASC-H and AGC cytology. 6,7 Several studies have already shown that the hrHPV testing has higher sensitivity than cytology to detect cervical intraepithelial neoplasia grade 2 or worse ( $\geq$ CIN 2), besides its higher reproducibility, compared with the Pap test. Also, HPV-based cervical screening provides greater protection against invasive cancer than cytological-based screening. ${ }^{8-12}$ Nevertheless, the age must be considered when interpreting hrHPV testing results, adolescent and young women show significantly higher rates of HPV infection than women aged $\geq 30$ years old. ${ }^{13}$

Socioeconomic, geographical, social and cultural factors seem to contribute to the lower participation of women who belong to ethnical minorities on screening programs. ${ }^{14}$ Atypical squamous cells of undetermined significance, LSIL, ASC-H and AGC management increases the demand for colposcopy; however, most of these abnormalities have a benign origin or regress spontaneously. We hypothesized that hrHPV testing may improve the closure of these abnormal cytologies in the context of public health, especially in the SUS. The present study aimed to evaluate the performance of the hybrid capture 2 (HC2) technique for hrHPV and cytological exam in women with previous cytology classified as ASC-US, LSIL, ASC-H, and AGC to detect $\geq$ CIN 2 . 


\section{Methods}

\section{Casuistry}

This is a cross-sectional study conducted at the Adolfo Lutz Institute, the central public health laboratory of the state of São Paulo, Brazil, with convenience samples of women undergoing routine cervical screening between July 2013 and September 2015. The participants of the present study are residents of Vale do Ribeira, a region in the state of São Paulo, which has a part of the population living under highly vulnerable conditions, considering that $25.91 \%$ is rural population and $7.65 \%$ live under extreme poverty conditions. ${ }^{15,16}$ The samples were referred from the Leopoldo Bevilacqua Regional Hospital or from the Vale do Ribeira Region Basic Health Units due to previous cytology classified as ASC-US, LSIL, ASC-H, and AGC, as shown in - Fig. 1.

Out of the total of 359 women who were cotested using SurePath (Becton Dickinson, TriPath Imaging, Burlington, NC, USA) liquid-based cytology samples, 183 women had uterine cervix biopsy collected in the same period of the cotest, 4 of them with inconclusive histopathological results, which were excluded from the casuistry. The participants signed the free informed consent, and the present study was approved by the Research Ethics Committee of the Instituto Adolfo Lutz (CAAE: 26042213.1.0000.0059).

\section{Repeat Cytology (CYTO 2)}

SurePath liquid-based samples were collected, with a cervical brush (Rovers Medical Devices, Lekstraat 10, NL-5347, KV Oss, The Netherlands). The liquid-based cytology (LBC) was processed and stained in an automated manner, according to the manufacturer's instructions. Cytology evaluation was conducted by researchers and a pathologist with at least 10 years of experience in cytopathology following the Brazil- ian nomenclature for cytopathological terminology for reporting Pap test results. ${ }^{5}$

\section{Hybrid Capture 2}

Human papillomavirus was analyzed by HC2 assay (Qiagen, Gaithersburg, Maryland, EUA) for group B viruses (16, 18, 31, $33,35,39,48,51,52,56,58,59$ and 68$)$ using the residual LBC specimen, according to the instructions of the manufacturer. The viral load was determined through the quantification of light emission and expressed as a relation of the relative light unit (RLU) with the positive control (PCB), RLU/PCB. Results $<1.0$ were considered negative (hrHPV-), and results $\geq 1.0$ were considered positive (hrHPV + ).

\section{Histopathological Exam}

We analyzed 179 uterine cervix fragments, fixed in formalin, histologically processed, included in paraffin, submitted to $3-\mu \mathrm{m}$ cuts and stained with hematoxylin and eosin. Microscopical analysis was made by one single pathologist with $>30$ years of experience and was classified as cervicitis, cervical intraepithelial neoplasia grade 1,2 or 3 , and squamous cell carcinoma.

\section{Statistical Analysis}

The analyses were stratified by overall; aged groups: women $<30$ years old and women $\geq 30$ years old; and according to the previous cytology abnormalities: ASC-US, LSIL, ASC-H, and AGC. The cutoff for HC2 for hrHPV was relative light units (RLU) $\geq 1 \mathrm{pg} / \mathrm{mL}$ and for Repeat Cytology (CYTO 2) it was ASC-US.

We calculated the frequency of $\mathrm{HC} 2$ for hrHPV + and CYTO 2 positive (CYTO $2+$ ). The statistical differences between $\mathrm{HC} 2$ for hrHPV + and CYTO $2+$ frequencies were assessed by Exact confidence intervals, computed by the method of

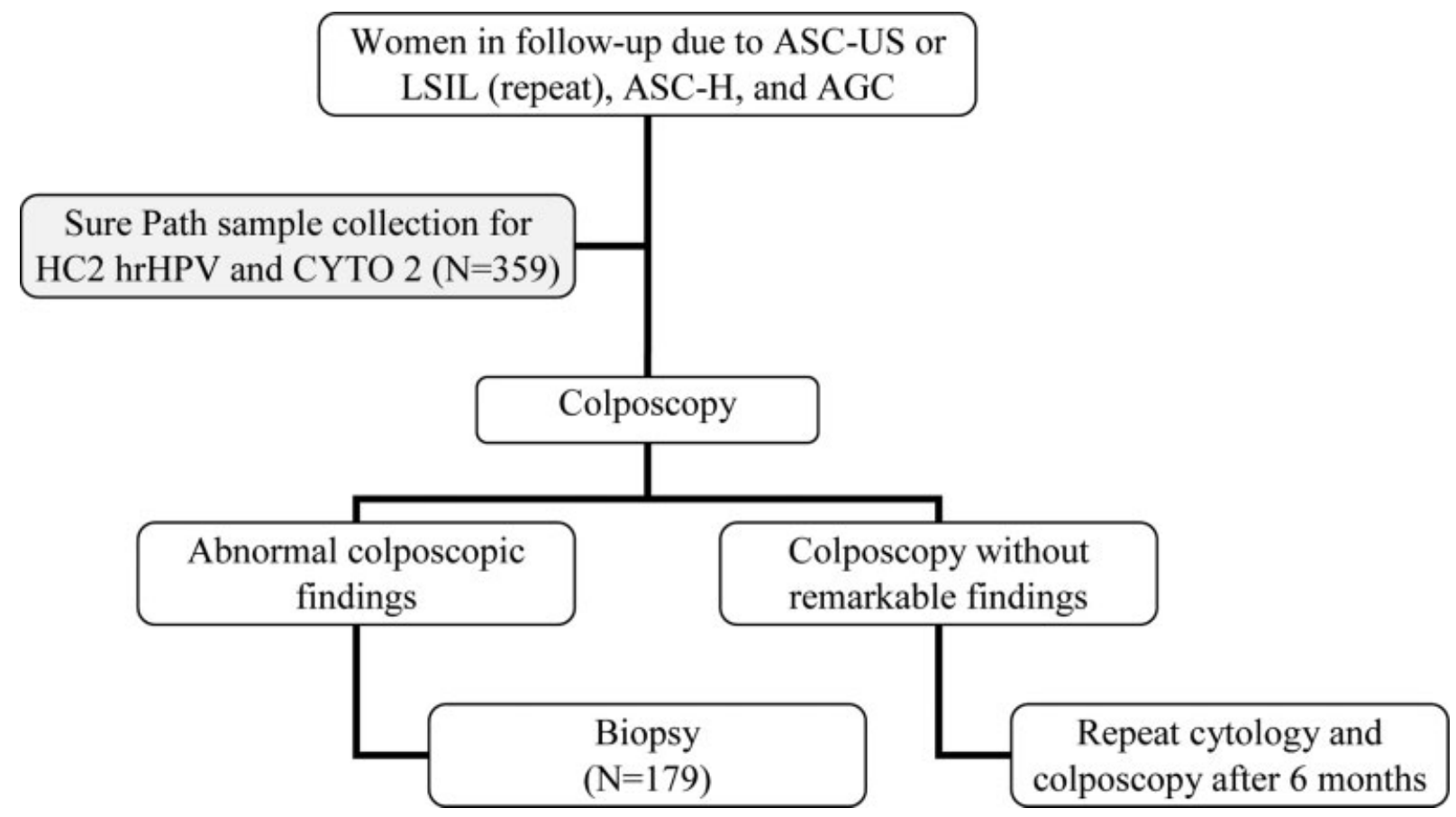

Fig. 1 Simplified diagram of women follow-up due to ASC-US, LSIL, ASC-H, and AGC, with the insertion point of the present research. 
Table 1 Criteria for classifying cases as true positive, false positive, true negative and false negative, based on results of HC2 for hrHPV and CYTO 2

\begin{tabular}{lll}
\hline & HC2 for hrHPV & CYTO 2 \\
\hline True positive & hrHPV positive & CYTO 2 positive \\
& with $\geq$ CIN 2 & with $\geq$ CIN 2 \\
False positive & hrHPV positive & CYTO 2 positive \\
& without $\geq$ CIN 2 & without $\geq$ CIN 2 \\
True negative & hrHPV negative & CYTO 2 negative \\
& without $\geq$ CIN 2 & without $\geq$ CIN 2 \\
False negative & hrHPV negative & CYTO 2 negative \\
& wtih $\geq$ CIN 2 & with $\geq$ CIN 2 \\
\hline
\end{tabular}

Abbreviations: CIN 2: cervical intraepithelial neoplasia grade 2; CYTO 2 , repeat cytology; HC 2, hybrid capture 2; hrHPV; high-risk human papillomavirus.

Table 2 Formulas for test performance

\begin{tabular}{ll}
\hline Sensitivity & True Positive/(False Negative + True Positive) \\
Specificity & True Negative/(False Positive + True Negative) \\
PPV & $\begin{array}{l}\text { sensitivity. prevalence/[sensitivity. } \\
\text { prevalence + (1-specificity). (1-prevalence)] }\end{array}$ \\
NPV & $\begin{array}{l}\text { specificity. (1-prevalence)/[(1-sensitivity). } \\
\text { prevalence + specificity. (1-prevalence)] }\end{array}$ \\
Accuracy & $\begin{array}{l}\text { sensitivity. prevalence }+ \text { Specificity. } \\
\text { (1-prevalence) }\end{array}$ \\
\hline
\end{tabular}

Abbreviations: NPV, negative predictive value; PPV, positive predictive value.

Clopper and Pearson using the GraphPad Quickcalcs Software program (GraphPad, La Jolla, CA, USA)

Histology was considered the gold standard method for the diagnosis of CIN. For performance evaluation of the HC2 for hrHPV and CYTO 2, women with cervicitis and CIN 1 were classified as absence of disease. Women with CIN 2, CIN 3, and squamous cell carcinoma ( $\geq$ CIN 2 ) were classified as presence of disease. There was no adenocarcinoma in the samples studied.
The performance evaluations were calculated using MEDCALC (Medcalc Software Ltd, Ostend, Belgium) ${ }^{17}$ easy-to-use statistical software (https://www.medcalc.org/calc/diagnostic_test.php). Confidence intervals (CIs) of 95\% for sensitivity, specificity and accuracy are "exact" Clopper-Pearson CIs, and for the positive predictive value (PPV) and negative predictive value (NPV) are standard logit confidence intervals given by Mercaldo et al. ${ }^{18}$ - Table 1 shows the criteria for defining positive and negative cases for statistical analysis, and - Table 2 shows the definitions of the sensitivity, specificity, PPV, NPV, and accuracy.

\section{Results}

The HC2 test for hrHPV and cytology was conducted on liquid-based material in 359 women. The mean age of the participating women was 39.8 years old (15 to 79 years old), with mean ages of 37.0 years old for women with hrHPV +, 39.1 years old for women with CYTO $2+, 41.1$ years old for women with hrHPV-, and 40.9 years old for women with CYTO 2-.

\section{Distribution and Percentage of HC2 for hrHPV and CYTO 2 Positivity}

The hrHPV + and CYTO 2+ absolute and relative frequencies, their respective $95 \% \mathrm{CIs}$, and the total of analyzed samples are described in - Table 3, stratified by overall; age groups (women $<30$ years old and women aged $\geq 30$ years old); and previous cytologic abnormalities (ASC-US, LSIL, ASC-H, and AGC). Overall, the hrHPV + rate was lower than the CYTO $2+$ rate. Women aged $\geq 30$ years old showed a lower hrHPV + rate than CYTO 2 + rate. The hrHPV + rate in women $<30$ years old was significantly higher than in women aged $\geq 30$ years old; however, there was no significant difference between CYTO $2+$ rate in women $<30$ years old and in women aged $\geq 30$ years old. According to the previous cytologic abnormalities stratification, we did not observe a statistical difference between hrHPV + and CYTO 2+ frequencies ( - Table $\mathbf{3}$ ).

Table 3 Distribution and percentage of HC2 for hrHPV + and CYTO 2+ stratified by overall, age groups and previous cytological abnormalities

\begin{tabular}{lllllc}
\hline & hrHPV $+(\%)$ & $95 \% \mathrm{Cl}$ & CYTO 2+ (\%) & $95 \% \mathrm{Cl}$ & Total \\
\hline Overall & $113(31.5)$ & $0.27-0.37$ & $170(47.4)$ & $0.42-0.53$ & $0.41-0.62$ \\
$<30$ years old & $45(45.5)$ & $0.35-0.56$ & $51(51.5)$ & $119(45.8)$ & $0.40-0.52$ \\
$\geq 30$ years old & $68(26.2)$ & $0.21-0.32$ & & \\
Previous cytology abnormalities & $25(20.5)$ & & $44(36.1)$ & $0.28-0.45$ \\
ASC-US & $54(38.6)$ & $0.14-0.29$ & $68(48.6)$ & $0.40-0.57$ & 122 \\
LSIL & $30(43.5)$ & $0.30-0.47$ & $45(65.2)$ & $0.53-0.76$ & 140 \\
ASC-H & $4(14.3)$ & $0.32-0.56$ & $13(46.4)$ & $0.28-0.66$ & 69 \\
AGC & & $0.04-0.33$ & 28 \\
\hline
\end{tabular}

Abbreviations: AGC, atypical glandular cells; ASC-H, atypical squamous cells, cannot exclude high-grade squamous intraepithelial lesions; ASC-US, atypical squamous cells of undetermined significance; CYTO2 + , repeat cytology atypical squamous cells of undetermined significance or worse; hrHPV + , hybrid capture 2 for high-risk human papillomavirus (RLU > 1pg/mL); LSIL, low-grade squamous intraepithelial lesion. 
Table 4 Distribution and prevalence of $\geq$ CIN 2 stratified by overall, age groups and previous cytologic abnormalities

\begin{tabular}{llll}
\hline & $\geq$ CIN 2 & Prevalence & Total \\
\hline $\begin{array}{l}\text { Overall } \\
\text { Age groups }\end{array}$ & 21 & 11.7 & 179 \\
$<30$ years old & 7 & 14.0 & \\
$\geq 30$ years old & 14 & 10.9 & 50 \\
Previous cytology abnormalities & & 129 \\
ASC-US & 3 & 7.1 & \\
LSIL & 5 & 8.2 & 43 \\
ASC-H & 11 & 18.3 & 61 \\
AGC & 2 & 12.5 & 60 \\
\hline
\end{tabular}

Abbreviations: AGC, atypical glandular cells; ASC-H, atypical squamous cells, cannot exclude high-grade squamous intraepithelial lesions; ASCUS, atypical squamous cells of undetermined significance; CIN 2: cervical intraepithelial neoplasia grade 2 .

\section{Performance of HC2 for hrHPV and CYTO 2}

The performance of HC2 for hrHPV and CYTO 2 was calculated based on the biopsy results. - Table 4 shows the distribution and prevalence of $\geq$ CIN 2 in a total of women with the histopathological exam. The HC2 for hrHPV performance is shown in -Table 5, and CYTO 2 performance is shown in - Table 6 , both assessed in the population with biopsy (-Table 4).

The specificity and accuracy of the HC2 for hrHPV in women aged $\geq 30$ years old were higher than in women $<30$ years old. There was no statistical difference between the performance of HC2 for hrHPV in women with previous ASC-US/LSIL and ASC-H/AGC (-Table 5).

There was no statistical difference between the performance of CYTO 2 in women $<30$ years old and in women $\geq 30$ years old, and between previous ASC-US/LSIL and ASC-H/AGC ( - Table 6).

Overall, the HC2 for hrHPV showed significantly higher performance than CYTO 2 for the detection of $\geq$ CIN 2 in the following categories: specificity $(65.8 \%, 95 \% \mathrm{CI}=57.9-73.2$, and $43.7 \%, 95 \% \mathrm{CI}=35.8-51.8$, respectively), PPV (26.0\%, 95\% $\mathrm{CI}=21.4-31.3$, and $17.6 \%, 95 \% \mathrm{CI}=14.9-20.6$, respectively), and accuracy $(68.7 \%, 95 \% \mathrm{CI}=61.4-75.4$, and $49.2 \%, 95 \%$ $\mathrm{CI}=41.6-56.7$, respectively). The HC2 for hrHPV in women $\geq 30$ years old showed a significantly higher performance than CYTO 2 for the detection of $\geq$ CIN 2 regarding specificity (75.7\%, 95\% $\mathrm{CI}=66.8-83.2$, and $46.1 \%, 95 \% \mathrm{CI}=36.8-55.6$, respectively), $\mathrm{PPV}(31.7 \%, 95 \% \mathrm{CI}=24.6-39.8$, and $17.3 \%$, $95 \% \mathrm{CI}=14.4-20.8$, respectively), and accuracy $(77.5 \%, 95 \%$ $\mathrm{CI}=69.3-84.4$, and $51.2 \%, 95 \% \mathrm{CI}=42.2-60.1$, respectively). There was no statistic difference between HC2 for hrHPV and CYTO 2 performance in women $<30$ years old. Women with previous ASC-H/AGC showed a significant higher performance of HC2 for hrHPV than CYTO 2 for the detection of $\geq$ CIN 2 regarding specificity $(71.4 \%, 95 \% \mathrm{CI}=58.7-82.1$, and $34.9 \%, 95 \% \mathrm{CI}=23.2-48.0$, respectively), PPV (37.9\%, 95\% $\mathrm{CI}=28.0-49.0$, and $21.2 \%, 95 \% \mathrm{CI}=16.7-26.5$, respectively), and accuracy $(73.7 \%, 95 \% \mathrm{CI}=62.2-83.1$, and $43.4 \%, 95 \%$ $\mathrm{CI}=32.1-55.3$, respectively). There was no statistic difference between HC2 for hrHPV and CYTO 2 in women with ASC-US/LSIL ( - Tables 5 and $\mathbf{6}$ ).

\section{Discussion}

The greater specificity, PPV and accuracy for $\geq$ CIN 2 detection observed in HC2 for hrHPV assay concerning repeat cytology assay observed in the present study performed in women from the Vale do Ribeira region with previous cytology abnormalities suggest that the biomolecular method could improve the triage for the colposcopic referral, especially in women aged $\geq 30$ years old.

Table 5 HC2 for hrHPV performance stratified by overall, age groups and previous cytology abnormalities

\begin{tabular}{|c|c|c|c|c|c|c|c|c|c|c|c|}
\hline & $n$ & TP & $\mathrm{FP}$ & $\mathrm{FN}$ & $\mathrm{TN}$ & $\begin{array}{l}\text { hrHPV + } \\
(\%)\end{array}$ & $\begin{array}{l}\text { Sensitivity } \\
(95 \% \mathrm{CI})\end{array}$ & $\begin{array}{l}\text { Specificity } \\
(95 \% \mathrm{Cl})\end{array}$ & $\begin{array}{l}\text { PPV } \\
(95 \% \mathrm{CI})\end{array}$ & $\begin{array}{l}\text { NPV } \\
(95 \% \mathrm{CI})\end{array}$ & $\begin{array}{l}\text { Accuracy } \\
(95 \% \mathrm{Cl})\end{array}$ \\
\hline $\begin{array}{l}\text { Overall } \\
\text { (age } 15-79 \text { years old) }\end{array}$ & 179 & 19 & 54 & 2 & 104 & 40.8 & $\begin{array}{l}90.5 \\
(69.6-98.8)\end{array}$ & $\begin{array}{l}65.8 \\
(57.9-73.2)\end{array}$ & $\begin{array}{l}26.0 \\
(21.4-31.3)\end{array}$ & $\begin{array}{l}98.1 \\
(93.3-99.5)\end{array}$ & $\begin{array}{l}68.7 \\
(61.4-75.4)\end{array}$ \\
\hline \multicolumn{12}{|l|}{ Age groups } \\
\hline$<30$ years old & 50 & 6 & 26 & 1 & 17 & 64.0 & $\begin{array}{l}85.7 \\
(42.1-99.6)\end{array}$ & $\begin{array}{l}39.5 \\
(25.0-56.0)\end{array}$ & $\begin{array}{l}18.8 \\
(13.6-25.4)\end{array}$ & $\begin{array}{l}94.4 \\
(72.7-99.1)\end{array}$ & $\begin{array}{l}46.0 \\
(31.8-60.7)\end{array}$ \\
\hline$\geq 30$ years old & 129 & 13 & 28 & 1 & 87 & 31.8 & $\begin{array}{l}92.9 \\
(66.1-99.8)\end{array}$ & $\begin{array}{l}75.7 \\
(66.8-83.2)\end{array}$ & $\begin{array}{l}31.7 \\
(24.6-39.8)\end{array}$ & $\begin{array}{l}98.9 \\
(92.9-99.8)\end{array}$ & $\begin{array}{l}77.5 \\
(69.3-84.4)\end{array}$ \\
\hline \multicolumn{12}{|c|}{ Previous cytology abnormalities } \\
\hline ASC-US/LSIL & 103 & 8 & 36 & - & 59 & 38.2 & $\begin{array}{l}100 \\
(63.1-100.0)\end{array}$ & $\begin{array}{l}62.1 \\
(51.6-71.9)\end{array}$ & $\begin{array}{l}18.2 \\
(14.7-22.3)\end{array}$ & $\begin{array}{l}100 \\
-\end{array}$ & $\begin{array}{l}65.1 \\
(55.0-74.2)\end{array}$ \\
\hline ASC-H/AGC & 76 & 11 & 18 & 2 & 45 & 42.7 & $\begin{array}{l}84.6 \\
(54.5-98.1)\end{array}$ & $\begin{array}{l}71.4 \\
(58.7-82.1)\end{array}$ & $\begin{array}{l}37.9 \\
(28.0-49.0)\end{array}$ & $\begin{array}{l}95.7 \\
(86.2-98.8)\end{array}$ & $\begin{array}{l}73.7 \\
(62.3-83.1)\end{array}$ \\
\hline
\end{tabular}

Abbreviations: AGC, atypical glandular cells; ASC-H, atypical squamous cells, cannot exclude high-grade squamous intraepithelial lesions; ASC-US, atypical squamous cells of undetermined significance; FN, false negatives (HPV negative, $\geq$ CIN 2); FP, false positives (HPV positive, $\leq$ CIN 1); LSIL, low-grade squamous intraepithelial lesion; NPV, negative predictive value; PPV, positive predictive value; TN, true negatives (HPV negatives, $\leq$ CIN 1 ); TP; true positives (HPV positive $\geq$ CIN 2).

Adapted from Cotton et al. (2010).21 
Table 6 CYTO 2 performance stratified by the result of previous cytology results

\begin{tabular}{|c|c|c|c|c|c|c|c|c|c|c|c|}
\hline & $\mathrm{n}$ & TP & FP & FN & TN & $\begin{array}{l}\text { Cyto } \\
2+(\%)\end{array}$ & $\begin{array}{l}\text { Sensitivity } \\
(95 \% \mathrm{CI})\end{array}$ & $\begin{array}{l}\text { Specificity } \\
(95 \% \mathrm{Cl})\end{array}$ & $\begin{array}{l}\text { PPV } \\
(95 \% \mathrm{CI})\end{array}$ & $\begin{array}{l}\text { NPV } \\
(95 \% \mathrm{CI})\end{array}$ & $\begin{array}{l}\text { Accuracy } \\
(95 \% \mathrm{Cl})\end{array}$ \\
\hline $\begin{array}{l}\text { Overall } \\
\text { (age } 15-79 \text { years old) }\end{array}$ & 179 & 19 & 89 & 2 & 69 & 60.3 & $\begin{array}{l}90.5 \\
(69.6-98.8)\end{array}$ & $\begin{array}{l}43.7 \\
(35.8-51.8)\end{array}$ & $\begin{array}{l}17.6 \\
(14.9-20.6)\end{array}$ & $\begin{array}{l}97.2 \\
(90.1-99.2)\end{array}$ & $\begin{array}{l}49.2 \\
(41.6-56.7)\end{array}$ \\
\hline \multicolumn{12}{|l|}{ Age groups } \\
\hline$<30$ years old & 50 & 6 & 27 & 1 & 16 & 66.0 & $\begin{array}{l}85.7 \\
(42.1-99.6)\end{array}$ & $\begin{array}{l}37.2 \\
(23.0-53.3)\end{array}$ & $\begin{array}{l}18.2 \\
(13.2-24.5)\end{array}$ & $\begin{array}{l}94.1 \\
(71.4-99.0)\end{array}$ & $\begin{array}{l}44.0 \\
(30.0-58.8)\end{array}$ \\
\hline$\geq 30$ years old & 129 & 13 & 62 & 1 & 53 & 58.1 & $\begin{array}{l}92.9 \\
(66.1-99.8)\end{array}$ & $\begin{array}{l}46.1 \\
(36.8-55.6)\end{array}$ & $\begin{array}{l}17.3 \\
(14.4-20.8)\end{array}$ & $\begin{array}{l}98.2 \\
(88.8-99.7)\end{array}$ & $\begin{array}{l}51.2 \\
(42.2-60.1)\end{array}$ \\
\hline \multicolumn{12}{|c|}{ Previous cytology abnormalities } \\
\hline ASC-US/LSIL & 103 & 8 & 49 & - & 46 & 54.4 & $\begin{array}{l}100 \\
(63.1-100.0)\end{array}$ & $\begin{array}{l}48.4 \\
(38.0-58.9)\end{array}$ & $\begin{array}{l}14.0 \\
(11.8-16.6)\end{array}$ & 100.0 & $\begin{array}{l}52.4 \\
(42.4-62.4)\end{array}$ \\
\hline ASC-H/AGC & 76 & 11 & 41 & 2 & 22 & 68.4 & $\begin{array}{l}84.6 \\
(54.6-98.1)\end{array}$ & $\begin{array}{l}34.9 \\
(23.2-48.0)\end{array}$ & $\begin{array}{l}21.2 \\
(16.7-26.5)\end{array}$ & $\begin{array}{l}91.7 \\
(74.7-97.6)\end{array}$ & $\begin{array}{l}43.4 \\
(32.1-55.3)\end{array}$ \\
\hline
\end{tabular}

Abbreviations: AGC, atypical glandular cells; ASC-H, atypical squamous cells, cannot exclude high-grade squamous intraepithelial lesions; ASC-US, atypical squamous cells of undetermined significance; FN, false negatives (CYTO 2 negative, $\geq$ CIN 2); FP, false positives (CYTO 2, $\leq$ CIN 1); LSIL, lowgrade squamous intraepithelial lesion; NPV, negative predictive value; PPV, positive predictive value; TN, true negatives (CYTO 2 negatives, $\leq$ CIN 1 ); TP; true positives (CYTO 2 positive $\geq$ CIN 2).

Adapted from Cotton et al. (2010). ${ }^{21}$

According to meta-analyses that assessed LBC and HC2 for the detection of $\geq$ CIN 2 in cross-sectional studies from Africa, Asia, North America, Oceania, Pacific, Central, and South America, the performance of LBC at the threshold of ASC-US or worse, with median sample size of 3,843 , the sensitivities of the tests ranged from 52 to $94 \%$, and specificities ranged from 52 to $98 \%$. For HC2, the median sample size was 4,195 , and the sensitivities of the tests ranged from 61 to $100 \%$, and specificities ranged from 64 to $95 \%{ }^{19}$ Compared with this study, our results showed similar values regarding HC2 sensitivity and specificity; however, the repeat cytology specificity was lower than those in the meta-analyses. Nevertheless, in the 10 articles included in the meta-analysis by Arbyn et $\mathrm{al}^{20}$ that evaluated the performance of the detection of $\geq$ CIN 2 by repeat cytology in samples with previous ASC-US, considering ASC-US as a cutoff, one showed a specificity of $45 \%$, a rate similar to that observed in our study. On the other hand, the same study showed $68.4 \%$ of absolute specificity in repeat cytology, $60.7 \%$ in $\mathrm{HC} 2,71.5 \%$ of absolute sensitivity in repeat cytology, and $90.9 \%$ in HC2. ${ }^{20}$ Furthermore, the results of sensitivity, specificity, and PPV showed considerable variation in the literature for both tests. $^{19-21}$

Women with ASC-US and LSIL abnormalities have a higher risk for underlying $\geq$ CIN 2 than women with normal cytology, and there has been controversy about the better management of the women with minor cytological abnormalities. ${ }^{22-24}$ In our study, we did not observe greater HC2 for hrHPV performance in women with previous ASC-US/LSIL than repeat cytology. Low-grade squamous intraepithelial lesion should be considered only as a transitory expression of the HPV infection due to its high rate of spontaneous regression, especially in young women. ${ }^{25,26}$ In women $<30$ years old, ASC-US and LSIL are common and, although they may indicate an underlying $\geq \mathrm{CIN} 2$, the spontaneous regression potential is high. ${ }^{27}$ Younger women, in comparison to older women, are more likely to have false-positive cytology and less likely to be tested positive for the hrHPV testing. ${ }^{28}$

Therefore, HC2 for hrHPV could improve the triage for colposcopy mainly in women aged $\geq 30$ years old, the specificity for this age group was significantly higher than repeat cytology and HC2 for hrHPV in women $<30$ years old. In Cotton et $\mathrm{al}^{21}$ the multicenter individually randomized controlled trial $(n=4,439)$ showed $63.9 \%$ specificity in HPV test for $\geq$ CIN 2 detection in women aged between 20 and 59 years old with recruitment based on morphological findings as mild dyskaryosis and borderline nuclear abnormalities, similar to our study. Nevertheless, in the same study, the specificity increases along with the age group, with higher specificity in older women. ${ }^{21}$

According to the meta-analysis by Arbyn et al, ${ }^{20}$ the triage of women with a cytological test result of ASC-US using the HC2 test is more sensitive, and equally specific to repeat cytology to detect underlying $\geq$ CIN2. The triage of women with a cytological test result of LSIL through the HC2 test is more sensitive but substantially less specific than repeat cytology to detect $\geq$ CIN2. The specificity of HC2 improves for older women. ${ }^{20}$ On the other hand, its lower specificity could have cost implications because of the referral of a large number of women with false-positive results to colposcopy, and the PPV should be considered for colposcopy referral. ${ }^{19,20}$ In our study, we observed a similar sensitivity between HC2 for hrHPV and repeated cytology, but greater specificity and PPV in the hrHPV test, especially in women $\geq 30$ years old. However, we had some limitations, as a small casuistry and analysis from women of a specific geographic region, which could affect the predictive value. Therefore, in practice, for the introduction of HPV assay in the Brazilian public health system, cost-effectiveness studies with a larger and more diversified casuistry will be necessary.

The cytological abnormalities classified as ASC-H are frequently associated with high positivity rates for hrHPV, with a 
relatively high risk of $\geq$ CIN 2 , ranging from 13 to $66 \%{ }^{7}$ However, these abnormalities are also associated with benign conditions, such as squamous metaplasia with degenerative characteristics, atrophy, reserve cell hyperplasia, hormonal effect, among others. ${ }^{29}$ Our study detected hrHPV in $43.5 \%$ of the ASC-H, and the prevalence of $\geq$ CIN 2 was $18.3 \%$. A Brazilian study with women assisted at private clinics reported positivity for hrHPV testing in 67.7\% (40/68) and 50\% (17/34) prevalence of $\geq$ CIN2 in women with ASC-H. ${ }^{30}$ Although the hrHPV test may assist in the differentiation between benign conditions and pre-neoplastic lesions, false-negative for $\geq$ CIN 2 may also occur. In the present study, HC2 was positive in $81.8 \%$ of the ASC-H with histopathological $\geq$ CIN 2. A study made in Belgium showed that $3 \%$ (1/32) of the ASC-H associated with $\geq$ CIN 2 tested negative on HC2 for hrHPV. ${ }^{31}$

For the AGC category, a substantially higher association is observed for CIN than the ASC-US and LSIL categories. ${ }^{32}$ Some studies suggest that AGC may precede malignant cervical or endometrial neoplasia and that it is associated with an increased risk of $\geq$ CIN 2 and of underlying in situ or invasive adenocarcinoma. ${ }^{33,34}$ On the other hand, these abnormalities can be associated with benign conditions, such as tubal metaplasia, tubular hyperplasia or polyps. ${ }^{35}$ One study from Ireland showed that out of 146 women referred to colposcopy following a single AGC with histologic results, 30 (20.5\%) were diagnosed with $\geq$ CIN 2 (CIN 2, CIN 3, adenocarcinoma and cancer). ${ }^{36}$ In our study, the $\geq \mathrm{CIN} 2$ prevalence for the women submitted to biopsy due to AGC was $12.5 \%$.

In Brazil, women with ASC-H and AGC are referred immediately to colposcopy. Women with biopsies without $\geq$ CIN 2 are kept on a semi-annual follow-up with cytology and colposcopy until the exclusion of invasive disease. ${ }^{5}$ In the present study, HC2 for hrHPV had greater performance in women with previous ASC-H/AGC than repeat cytology. Therefore, women with persistent ASC-H or AGC without significant colposcopy could benefit from the result of the hrHPV test, since its positivity may indicate the need to investigate the endocervical canal and hrHPV negatives samples reinforce the hypothesis that these cytological abnormalities are probably not associated to $\geq$ CIN $2 .{ }^{5}$ Thus, the work overload may be minimized on mediumcomplexity units, as well as the stress and anxiety of women with these types of cytological results.

Some aspects may have caused bias in our results. Women were referred for colposcopy based on previous cytology abnormalities, which avoided the possibility of management-based on hrHPV positivity influencing on the ascertainment of $\geq$ CIN 2. Also, we did not obtain the colposcopy results of women without biopsy, neither information about the evaluation of the transformation zone of these women. The participants of the present study were in follow-up due to mild and borderline abnormalities, and women with HSIL or worse in cytology results were not included.

The strength of our study is that it is a routine extracted from the Brazilian SUS reality, without changes in the recommended guidelines. Moreover, it included women from the Vale do Ribeira, a low human development index region, with limited access to biomolecular tests.

\section{Conclusion}

Overall, HC2 for hrHPV improved performance in the detection of $\geq$ CIN 2, without compromising sensitivity concerning the repeat cytology, being greater for women $\geq 30$ years old. In women with previous ASC-US/LSIL, hrHPV testing had the same impact as the repeat cytology. In previous ASC-H/AGC, the hrHPV test had greater performance. Therefore, HC2 for hrHPV could be useful in the colposcopy triage of women with previous abnormalities, especially in women $\geq 30$ years old, and the negative result of HC2 for hrHPV in women with ASC-H/AGC, without significant lesions confirmed by histopathology, makes it safer for them to return to the triennial screening protocol.

\section{Contributions}

Lorente S.: conception and design, acquisition, analysis and interpretation of data and drafting of the article. Fernandes N. C. C. A.: conception and design, analysis and interpretation of data, critical review of the article and final approval of the version to be published. Etlinger-Colonelli D.: conception and design, analysis and interpretation of data and critical review of the article and final approval of the version to be published. Réssio R. A.: conception and design, analysis and interpretation of data, critical review of the article and final approval of the version to be published. Oliveira $S$. M. P.: conception and design, critical review of the article, and final approval of the version to be published. Catarino $R$. M.: conception, design, critical review of the article and final approval of the version to be published.

\section{Conflict of Interests}

Dr. Lorente has nothing to disclose.

\section{Acknowledgments}

To the professionals from the Pathological Anatomy Center of the Instituto Adolfo Lutz, to Juliana Mariotti Guerra, from the quantitative pathology center, to the physicians and nurses from the health units of Vale do Ribeira, and to Claudio Roberto Meinsz and Rosangela Platero de Miranda, from the Hospital Regional Doutor Leopoldo Bevilacqua. DECIT/SCTIE/MS, thought CNPq, with support from FAPESP and SES-SP for the funding of the project.

\section{References}

1 Ministério da Saúde. Instituto Nacional de Câncer [Internet]. Câncer do colo do útero. Rio de Janeiro: INCA; 2018 [cited 2018 Apr 2]. Available from: https://www.inca.gov.br/tipos-de-cancer/cancer-do-colo-do-utero

2 Arbyn M, Sasieni P, Meijer CJLM, Clavel C, Koliopoulos G, Dillner J. Chapter 9: Clinical applications of HPV testing: a summary of metaanalyses. Vaccine. 2006;24(Suppl 3(S3):78-89. Doi: 10.1016/j. vaccine.2006.05.117

3 Rijkaart DC, Berkhof J, Rozendaal L, van Kemenade FJ, Bulkmans NWJ, Heideman DAM, et al. Human papillomavirus testing for the detection of high-grade cervical intraepithelial neoplasia and cancer: final results of the POBASCAM randomised controlled trial. Lancet Oncol. 2012;13(01):78-88. Doi: 10.1016/S14702045(11)70296-0 
4 Richardson LA, El-Zein M, Ramanakumar AV, Ratnam S, SangwaLugoma G, Longatto-Filho A, et al; PEACHS (Pap Efficacy After Cervical HPV Status) Study Consortium. HPV DNA testing with cytology triage in cervical cancer screening: Influence of revealing HPV infection status. Cancer Cytopathol. 2015;123(12): 745-754. Doi: $10.1002 /$ cncy. 21596

5 Ministério da Saúde. Instituto Nacional de Câncer José Alencar Gomes da Silva. Coordenação de Prevenção e Vigilância. Divisão de Detecção Precoce e Apoio à Organização de Rede [Internet]. Diretrizes brasileiras para o rastreamento do câncer do colo do útero. 2a ed. Rio de JaneiroINCA2016 [cited 2018 Apr 12]. Available from: https://www.inca.gov.br/sites/ufu.sti.inca.local/ files//media/document//diretrizesparaorastreamento docancerdocolodoutero_2016_corrigido.pdf

6 Kyrgiou M, Kalliala I, Mitra A, Ng KYB, Raglan O, Fotopoulou C, et al. Immediate referral to colposcopy versus cytological surveillance for low-grade cervical cytological abnormalities in the absence of HPV test: A systematic review and a meta-analysis of the literature. Int J Cancer. 2017;140(01):216-223. Doi: 10.1002/ijc.30419

7 Xu L, Verdoodt F, Wentzensen N, Bergeron C, Arbyn M. Triage of ASC-H: A meta-analysis of the accuracy of high-risk HPV testing and other markers to detect cervical precancer. Cancer Cytopathol. 2016;124(04):261-272. Doi: 10.1002/cncy.21661

8 Cuzick J, Clavel C, Petry KU, Meijer CJLM, Hoyer H, Ratnam S, et al. Overview of the European and North American studies on HPV testing in primary cervical cancer screening. Int J Cancer. 2006; 119(05):1095-1101. Doi: 10.1002/ijc.21955

9 Ronco G, Giorgi-Rossi P, Carozzi F, Confortini M, Palma PD, Mistro AD, et al; New Technologies for Cervical Cancer screening (NTCC) Working Group. Efficacy of human papillomavirus testing for the detection of invasive cervical cancers and cervical intraepithelial neoplasia: a randomised controlled trial. Lancet Oncol. 2010;11 (03):249-257. Doi: 10.1016/S1470-2045(09)70360-2

10 Luttmer R, De Strooper LMA, Steenbergen RDM, Berkhof J, Snijders PJF, Heideman DAM, Meijer CJLM, et al. Management of high-risk HPV-positive women for detection of cervical (pre) cancer. Expert Rev Mol Diagn. 2016;16(09):961-974. Doi: 10.1080/14737159.2016.1217157

11 Arbyn M, Ronco G, Anttila A, Meijer CJLM, Poljak M, Ogilvie G, et al. Evidence regarding human papillomavirus testing in secondary prevention of cervical cancer. Vaccine. 2012;30(Suppl 5): F88-F99. Doi: 10.1016/j.vaccine.2012.06.095

12 Arbyn M, Buntinx F, Van Ranst M, Paraskevaidis E, Martin-Hirsch P, Dillner J. Virologic versus cytologic triage of women with equivocal Pap smears: a meta-analysis of the accuracy to detect high-grade intraepithelial neoplasia. J Natl Cancer Inst. 2004;96 (04):280-293. Doi: 10.1093/jnci/djh037

13 Zhao C, Moriarty AT, Ghofrani M, Husain M, Tambouret RH, Laucirica R, et al. Human papillomavirus testing and reporting rates in 2012: results of a College of American Pathologists national survey. Arch Pathol Lab Med. 2015;139(06):757-761. Doi: 10.5858/arpa.2014-0393-CP

14 Ginsburg O, Bray F, Coleman MP, Vanderpuye V, Eniu A, Kotha SR, et al. The global burden of women's cancers: a grand challenge in global health. Lancet. 2017;389(10071):847-860. Doi: 10.1016/ S0140-6736(16)31392-7

15 Silva BP, Stockmann D, Lúcio DdeS, Henna E, Rocha MCP, Junqueira FM. Expanding health access in the more vulnerable region in the state of São Paulo, Brazil: is this a reflection of the Mais Médicos (More Doctors) Program? Cien Saude Colet. 2016;21(09):2899-2906. Doi: 10.1590/1413-81232015219.15552016

16 Ministério do Desenvolvimento Agrário. Sistema de Informações Territoriais [Internet]. Composição Municipal do Território Vale do Ribeira - SP. 2018 [cited 2018 Apr 10]. Available from: http:// sit.mda.gov.br/download.php?ac=verMunTR\&m $=3542602$

17 MEDCALC®: easy-to-use statistical software [Internet]. 2018 [cited 2018 Apr 10]. Available from: https://www.medcalc.org/calc/diagnostic_test.php
18 Mercaldo ND, Lau KF, Zhou XH. Confidence intervals for predictive values with an emphasis to case-control studies. Stat Med. 2007; 26(10):2170-2183. Doi: 10.1002/sim.2677

19 Koliopoulos G, Nyaga VN, Santesso N, Bryant A, Martin-Hirsch PPL, Mustafa RA, et al. Cytology versus HPV testing for cervical cancer screening in the general population. Cochrane Database Syst Rev. 2017;8:CD008587. Doi: 10.1002/14651858.CD008587. pub2

20 Arbyn M, Roelens J, Simoens C, Buntix F, Paraskevaidis E, MartinHirsch PPL, Prendiville WJ, et al. Human papillomavirus testing versus repeat cytology for triage of minor cytological cervical lesions. Cochrane Database Syst Rev. 2013;(03):CD008054. Doi: 10.1002/14651858.CD008054.pub2

21 Cotton S, Sharp L, Little J, Cruickshank M, Seth R, Smart L, et al; Trial Of Management of Borderline and Other Low-grade Abnormal Smears Group. The role of human papillomavirus testing in the management of women with low-grade abnormalities: multicentre randomised controlled trial. BJOG. 2010;117(06): 645-659. Doi: 10.1111/j.1471-0528.2010.02519.x

22 Catteau X, Simon P, Noël JC. Evaluation of the oncogenic human papillomavirus DNA test with liquid-based cytology in primary cervical cancer screening and the importance of the ASC/SIL ratio: a Belgian study. ISRN Obstet Gynecol. 2014;2014:536495. Doi: $10.1155 / 2014 / 536495$

23 Khunamornpong S, Settakorn J, Sukpan K, Srisomboon J, Suprasert P, Siriaunkgul S. Performance of HPV DNA testing with hybrid capture 2 in triaging women with minor cervical cytologic abnormalities (ASC-US/LSIL) in Northern Thailand. Asian Pac J Cancer Prev. 2014;15(24):10961-10966

24 Bentley E, Cotton SC, Cruickshank ME, et al; Trial of Management of Borderline and Other Low-Grade Abnormal Smears (TOMBOLA) Group. Refining the management of low-grade cervical abnormalities in the UK National Health Service and defining the potential for human papillomavirus testing: a commentary on emerging evidence. J Low Genit Tract Dis. 2006;10(01):26-38. Doi: 10.1097/01.lgt.0000192695.93172.75

25 Ciavattini A, Clemente N, Tsiroglou D, et al. Follow up in women with biopsy diagnosis of cervical low-grade squamous intraepithelial lesion (LSIL): how long should it be? Arch Gynecol Obstet. 2017;295 (04):997-1003. Doi: 10.1007/s00404-017-4335-7

26 Massad LS, Einstein MH, Huh WK, Katki HA, Kinney WK, Schiffman M, et al; 2012 ASCCP Consensus Guidelines Conference. 2012 updated consensus guidelines for the management of abnormal cervical cancer screening tests and cancer precursors. Obstet Gynecol. 2013;121(04):829-846. Doi: 10.1097/AOG.0b013e3182883a34

27 Sundström K, Lu D, Elfström KM, Wang J, Andrae B, Dillner J, Sparén P. Follow-up of women with cervical cytological abnormalities showing atypical squamous cells of undetermined significance or low-grade squamous intraepithelial lesion: a nationwide cohort study. Am J Obstet Gynecol. 2017;216(01): 48.e1-48.e15. Doi: 10.1016/j.ajog.2016.07.042

28 The Atypical Squamous Cells of Undetermined Significance/LowGrade Squamous Intraepithelial Lesions Triage Study (ALTS) Group. Human papillomavirus testing for triage of women with cytologic evidence of low-grade squamous intraepithelial lesions: baseline data from a randomized trial. J Natl Cancer Inst. 2000;92(05):397-402

29 Davey DD, Greenspan DL, Kurtycz DFI, Husain M, Austin RM. Atypical squamous cells, cannot exclude high-grade squamous intraepithelial lesion: review of ancillary testing modalities and implications for follow-up. J Low Genit Tract Dis. 2010;14(03): 206-214. Doi: 10.1097/LGT.0b013e3181ca66a6

30 Oliveira GG, Oliveira JMDSC, Eleutério RMN, Barbosa RCC, Almeida PRC, Eleutério J Jr. Atypical Squamous cells: cytopathological findings and correlation with hpv genotype and histopathology. Acta Cytol. 2018;62(5-6):386-392. Doi: 10.1159/000489386

31 Noël JC, Simon P. Limitations on the detection rate of high-risk HPV by hybrid capture 2 methodology in high grade 
intraepithelial (HSIL) or atypical squamous cells-cannot exclude HSIL (ASC-H) cytological lesions with proved CIN2. Anal Cell Pathol (Amst). 2015;2015:746502. Doi: 10.1155/2015/746502

32 Irvin W, Evans SR, Andersen W, Jazaeri A, Taylor P, Stoler M, et al. The utility of HPV DNA triage in the management of cytological AGC. Am J Obstet Gynecol. 2005;193(02):559-565, discussion 565-567. Doi: 10.1016/j.ajog.2005.03.044

33 Verdoodt F, Jiang X, Williams M, Schnatz PF, Arbyn M. High-risk HPV testing in the management of atypical glandular cells: A systematic review and meta-analysis. Int J Cancer. 2016;138(02): 303-310. Doi: 10.1002/ijc.29424
34 Kim MK, Lee YK, Hong SR, Lim KT. Clinicopathological significance of atypical glandular cells on cervicovaginal Pap smears. Diagn Cytopathol. 2017;45(10):867-872. Doi: 10.1002/dc.23777

35 Norman I, Hjerpe A, Dillner J. Risk of high-grade lesions after atypical glandular cells in cervical screening: a population-based cohort study. BMJ Open. 2017;7(12):e017070. Doi: 10.1136/ bmjopen-2017-017070

36 Chummun K, Fitzpatrick M, Lenehan P, Boylan P, Mooney E, Flannelly G. Diagnostic and therapeutic dilemma associated with atypical glandular cells on liquid-based cervical cytology. Cytopathology. 2012;23(06):378-382. Doi: 10.1111/j.1365-2303.2012.00981.x 